\title{
Learning of Silc Pencak Silat Learning with Game for Muhammadiyah Tanjung Sari Elementary School Students in Medan City
}

\author{
Muhammad Andri Fahrian \\ Sports Education Postgraduate \\ Program \\ Medan State University \\ Medan, Indonesia \\ muhammad080685@gmail.com
}

\author{
Nurhayati Simatupang \\ Sports Education Postgraduate \\ Program \\ Medan State University \\ Medan, Indonesia \\ Runlife66@yahoo.comsuprayt@gma
}

\author{
Suprayitno \\ Sports Education Postgraduate \\ Program \\ Medan State University \\ Medan, Indonesia
}

\begin{abstract}
Learning of Pencak Silat Basic Motion With Games For Muhammadiyah Tanjung Sari Elementary School Students in the city of Medan.This research is motivated by the absence of standard (national) teaching materials for pencaksilat students for Muhammadiyah elementary school students, regarding pencak silat material submitted to their respective regions with the provisions of active teaching staff as members of TapakSuci.This is what causes the various pencak silat materials while pencak silat as a compulsory subject at Muhammadiyah schools.
\end{abstract}

This study aims to develop a basic motion learning model of pencak silat adjusted to the characteristics of the growth and development of elementary school children's movement skills. This research is a study using a model of development or research and development $(\mathrm{R} \& \mathrm{D})$ ).This research was conducted in several steps, namely: identification and problems, data collection, product design, design validation, design revision, product testing, product revision trial usage, product revision, mass production. esearch subjects in small groups are class $\mathbf{V}$ and large group trials are four classes $V$.

The results showed that the Development of Pencak Silat basic motion game development consisted of 1) potential problems 2) Data collection 3) Product design 4) Validation 5) Product revision 6) Product trial.Pencak Silat's basic motion game has 20 variations of games that fit the characteristics of early childhood.The results of expert validation on the effectiveness of pencak silat basic motion game products obtained an average aspect score of the answers of the three experts in a small trial of 3.66-4.22 with a percentage range of $74.28 \%$ $84.28 \%$. The results of expert validation on the effectiveness of pencak silat basic motion game products obtained an average aspect score of the answers of the three experts in a large trial of 4.22-4.69 with a percentage range of $84.28 \%-94.28 \%$.The results of respondents on the development of pencak silat basic motion obtained a small product trial percentage range of $\mathbf{7 9 . 8 1 \%} \mathbf{- 8 8 . 5 4}$ and trials of large products $\mathbf{8 5 . 4 1 \%} \mathbf{- 9 5 . 8 3 \%}$.

\section{Keywords: Learning, Pencak Silat, Early Age and Games}

\section{INTRODUCTION}

Indonesia is a developing country, currently trying to improve the quality and quantity of education, especially in the field of physical education By improving the quality of physical education, it is hoped that it can accelerate and bring closer to the achievement of the development goals of the Indonesian nation, namely creating a complete Indonesian human being in accordance with the Pancasila and the 1945 Constitution, thus making it clear that the field of education, especially physical education is very closely related to development goals National Education.

Physical Education is a medium to encourage the development of motor skills, physical abilities, knowledge, reasoning, appreciation of values (mental-emotional-spiritualspiritual-social), and the habit of healthy lifestyles that lead to stimulating balanced growth and development, systematically planned in order to achieve national education goals. The intended national education objective, stipulated in Law 20 of 2003 concerning the National Education System, Article 3, states that "National education functions to develop capabilities and shape the character and civilization of a nation with dignity in the context of developing the life of the nation, aiming at developing the potential of students so that humans believe devoted to God Almighty, noble, healthy, knowledgeable, capable, creative, independent and become citizens of a democratic and responsible ".

Learning physical sports and health education, the task of a teacher must be able to develop a variety of materials that can make students move and practice their basic mobility.Primary school age is a period of growth and development, multirateral motion is highly recommended because with multilateral can develop all the physical elements that exist at this time, therefore there is a reason not to provide special training.Characteristics of children at this age are still happy to play, therefore every material to be provided must be endeavored to have a playful element that is fun, but still does not leave the subject matter about what the child wants to achieve. With the creation of a sense of pleasure and excitement when learning physical education, then it will automatically arise motivation in children to continue to 
follow learning activities, especially in the field of physical education.

Physical education, sports and health in the Muhammadiyah School emphasizes Islamic education which involves all aspects of humanity both physical, spiritual, noble, activity and creative.n line with this, according to the Qaidah of the Dikdasmen Council "Muhammadiyah has the aim to form Muslim people who believe, have noble, competent, self-confident, love the motherland, develop knowledge and skills and do charity towards the realization of an Islamic society that is truly in accordance with Qur'an and Hadith guidelines ".

In accordance with the objectives of Muhammadiyah above, K. H. Ahmad Dahlan emphasized education that really needs to be upheld to build a large nation are: (1) Absolute education (2) Individual education (3) Social education.

Muhammadiyah education throughout Indonesia has martial arts extracurricular activities that must be followed by all students who are called Tapak Suci Putra Muhammadiyah or short with sacred treads originating from Islam which are sourced from the Koran and As-Sunnah which have the motto "With Faith and Ahlak I became strong, without faith and virtue I became weak".

A physical, sports and health education teacher who teaches at Muhammadiyah must be guided by the Koran and Sunnah and be able to make the learning process fun, creative, innovative, based on games. This condition is sometimes difficult for teachers to realize, even though there is a quantity that is very low, less innovative and does not master technology. Physical education teachers in general only assess student learning outcomes based on the final results after students make a movement of a learning material, not assessing the process during a movement carried out.

Based on information and interviews with Dr. Rony Syaifullah, M.Pd (Chief Coach of Pelatnas Pencak Silat) that pencak silat in the Muhammadiyah School refers to the national pilot Muhammadiyah Executive Board.The Muhammadiyah School makes pencak silat as a compulsory subject but a standard (national) curriculum has not been set, regarding pencak silat material being handed over to each region with the provision of active teaching staff as members of Tapak Suci. Hal inilah yang menyebabkan materi pencak silat beraneka ragam. Based on observations from a number of Muhammadiyah elementary schools in Medan, the material refers to technical training not to lead to multilateral basic movements, this condition has the effect that most students seem less enthusiastic in participating in pencak silat learning because the characteristics of pencak silat are very monotonous and almost has no element of play.This is justified by information from teachers at the Muhammadiyah School.

The researcher also sees the teacher who generates between practicing adult silat with silat learning for elementary school children and directly teaches about techniques in pencak silat.Students in Elementary Schools who are still in the category of children have the characteristics of playing and expressing pleasure.As we all know for learning physical education in elementary school is fun and games because we see the basic motion (not the harm of the motion).The abilities, needs, attention and interests of children differ from the abilities, needs, interests and attention of adults.Therefore, it is certainly not suitable if the teacher pours an exercise or sports program for adults to elementary school children. Children need programs that are specifically created with their interests and needs.

Learning at the elementary level needs to prioritize safety and healthy factors. Modification forms in terms of regulations, field size, and number of players.If not modified, students are often unable and fail to carry out the tasks given in the form of complex movements by the teacher. As a result of these conditions, students can become less happy with learning Physical education in sports and health.Teaching tasks that are complex skills can actually be done in an effort to modify complex motion tasks into simple motion tasks. For this reason the need for sports modification in Physical Education learning is absolutely necessary. The teacher in this case must have the ability to be able to modify the skills to be taught according to the level of child development.

Based on the conditions in the field the results of observations (interviews and answering questionnaires given to students and teachers) at one Muhammadiyah Elementary School in Medan. The results show that pencaksilat learning (tread Suci) with conventional learning is less desirable and interesting so students and teachers want a game model with a percentage of results ( $85 \%$ for students) and $(75 \%$ for teachers) of the questions answered.That is because the weight of the learning process, the boring learning atmosphere and other boredom, so that the innovation and creation of teachers is needed in developing various learning models so that the learning process does not become monotonous and boring. Students aged 10-12 years or grade 5 and 6 elementary school should have great motivation in learning movement because according to Hadisasmita and Syarifuddin (1999: 19) at the age of 10-12 years is the most appropriate age for the development of the basic skills needed later.There is no right or wrong here.

Characteristics of elementary school children who love to play, like to move, like to work in groups and like to feel or do something directly, making the right development model is given, namely various basic movements of pencak silat with games which of course the movements must support and relate to basic movements martial arts. In this case the researcher limits the basic movements of pencak silat which will be developed in the forms of games, namely the basic movements of hitting and kicking in pencak silat.

Related to the statements that have been stated above, the researcher concludes that most of the students at Muhammadiyah Elementary School do not enjoy learning and practicing pencak silat. So it is necessary to develop pencaksilat learning with games that can later be used as a solution to facilitate students in learning the basic movements of pencak silat more effectively and efficiently. 


\section{RESEARCH METHODS}

The research design carried out in this study was $R \& D$ research development that modified the basic movements of pencak silat in SD Muhammadiyah Medan with the approach of game methods. This research was carried out in the field of SD Muhammadiyah Tanjung Sari Medan City.When this research was carried out on April 152019 until July 15, 2019.

The steps in this study include 1) potential problems 2) Data collection 3) Product design 4) Design validation 5) Design revision 6) Product trial 7) Product revision 8) Usage trial 9) Product revision.Preliminary data collection techniques to get the potential problems to be studied were taken from literature studies, journals, observations and interviews conducted with students and teachers, questionnaires, porto polio, documentation.

Data analysis techniques in this research and development using descriptive analysis. All data collected was analyzed with descriptive statistical techniques which were quantitatively separated according to categories to sharpen the assessment which was then used to draw conclusions. Data analysis was conducted on expert reviews as a result of expert judgment, in addition qualitative data in the form of inputs and suggestions were also grouped and analyzed, the results of which were used for product revisions used in this case were the basic movements of pencak silat with the game method.

Data analysis is an important step in research and development activities. So that it can review the results of data that has been obtained previously. The data analysis technique used is adjusted to the type of data collected. Some things to consider in data analysis include:

a. Data analysis includes data organization procedures, reduction, data presentation, with tables, charts or graphs.

b. Data is classified based on the type and component of product being developed.

c. Data were analyzed descriptively and in the form of quantitative calculations.

d. Presentation of the results of data analysis is limited to things that are factual, without the interpretation of the developer, so as a basic assumption in revising the model.

e. In data analysis the use of calculations and statistical analysis is in line with the problems raised.

In this research and development data analysis technique used is a quantitative descriptive analysis technique with a percentage. his technique is used to analyze quantitative data obtained from observations of the learning process of pencak silat.

To determine the conclusions that have been reached, the following criteria are determined :
TABLE 1. PERCENTAGE ANALYSIS OF EVALUATION RESULTS BY TEST SUBJECTS

\begin{tabular}{|c|c|c|}
\hline Presentase & Information & Mean \\
\hline $80 \%-100 \%$ & Valid & Used \\
\hline $60 \%-79 \%$ & Valid & Used \\
\hline $50 \%-59 \%$ & Invalid & Not used \\
\hline$<50 \%$ & Invalid & Not used \\
\hline
\end{tabular}

Source: Sudjana (1990:131)

\section{RESULTS AND DISCUSSION}

Pencak Silat basic motion learning with this game is written in the form of a script or storyboard script that presents forms of learning the basic movements of pencak silat in a modified game form with a basic motion approach, which is applied in the forms of the game.

Overall, there are three general objectives to be revealed in the preliminary study, namely: (1) how intense physical education learning, especially in pencak silat material is in line with the characteristics of curriculum implementation as formulated (2) how important is the development of pencak silat learning with games in an effective and efficient learning process, as well as interesting (3)What obstacles and support are found in learning the basic silat pencak silat with the game.For this reason, researchers conducted:

\section{A. Potential Problems}

The results of observations to collect preliminary data for the needs of basic motion models based on pencak silat learning (tread Suci) with conventional learning are less desirable and interesting so students and teachers want a game model with performance results $(85 \%$ for students) and $(75 \%$ for teachers) of the questions answered. That is because the weight of the learning process, the boring learning atmosphere and other boredom, so that the innovation and creation of teachers is needed in developing various learning models so that the learning process does not become monotonous and boring. From the explanation of the results of the initial research or needs analysis above which states difficulties in learning pencak silat, the lack of variations in pencak silat learning activities, which do not and do not display pencak silat learning activities and the need for pencak silat learning models that stimulate student learning, from these things, it can be concluded that it is necessary to develop learning namely pencak silat basic motion learning with games for elementary school students grade $\mathrm{V}$.

The results of the preliminary study or field findings are further described and analyzed in order to obtain a formulation of the data collected. The formulation of these results is descriptive and analytical, with reference to the purpose of the preliminary study.

\section{B. Data collection}

Prepare things to create a learning scheme to be conveyed to students, to find out where the shortcomings of old learning are by looking at learning activities, especially pencak silat 
learning, and where the weaknesses and weaknesses and make learning plans in a way:

1. Making an expert evaluation institution for pencak silat learning materials (attachment 2)

2. Making basic psychomotor assessment instruments for pencak silat (appendix 3) as well as, the initial draft of learning of pencak silat.

\section{Desain Product}

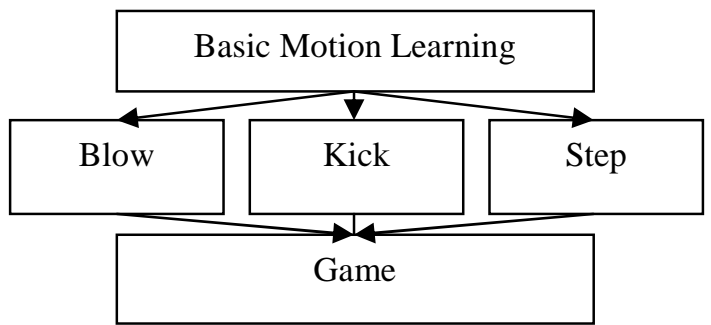

\section{Validasi}

\section{Product Validation}

Product validation on pencak silat basic motion games is validated by several experts including:

a. Sports Expert

Pencak silat's basic motion game product for an early age is validated by a sports expert namely Mr. Iwan Saputra, S.Pd., M.Pd as a lecturer in the Faculty of Sport Science, Medan State University.Product validation results from sports experts :

TABLE 2. SPORTS EXPERT PRODUCT VALIDATION RESULTS

\begin{tabular}{|c|c|c|c|}
\hline No & Rating stages & $\begin{array}{c}\text { Aspect } \\
\text { average }\end{array}$ & Presentase \\
\hline 1 & Preparation & 3,75 & $75 \%$ \\
\hline 2 & $\begin{array}{c}\text { Game Product } \\
\text { Making }\end{array}$ & 4 & $80 \%$ \\
\hline 3 & Product Rating & 3,25 & $65 \%$ \\
\hline
\end{tabular}

From the results of the assessment of pencak silat basic motion game products by sports experts obtained an average range of scores of $3.25-4.00$ with a percentage of $65 \%-80 \%$.

\section{b. Tread Holy Martial Arts Trainer}

Pencak silat basic motion game products for early age are validated by the expert of the tread holy, namely Mr. Paiman Sumardi, S.Pd as the leader of the tread holy school. The product validation results from the tread holy expert are:
TABLE 3. PRODUCT VALIDATION RESULTS OF TAPAK SUCI SWORDSMAN

\begin{tabular}{|c|c|c|c|}
\hline NO & $\begin{array}{c}\text { STAGE OF } \\
\text { ASSESSMENT }\end{array}$ & $\begin{array}{c}\text { AVERAGE } \\
\text { ASPECT }\end{array}$ & PRESENTASE \\
\hline 1 & Preparation & 4,25 & $85 \%$ \\
\hline 2 & Game Product Making & 4,16 & $83,33 \%$ \\
\hline 3 & Product Rating & 4,25 & $85 \%$ \\
\hline
\end{tabular}

From the results of the assessment of pencak silat basic motion game products by sports experts obtained an average range of scores of 4.16-4.25 with a percentage of $83.33 \%-85 \%$.

c. Muhammadiyah Physical Education Teacher Expert

Pencak silat's basic motion game product for early age is validated by an expert in martial arts teacher namely Mr. Eka Wahyudi, S.Pd as a martial arts teacher at SD Muhammadiyah namely:

TABLE 4. VALIDATION RESULTS OF PENCAK SILAT TEACHERS OF MUHAMMADIYAH TANJUNG SARI ELEMENTARY SCHOOL

\begin{tabular}{|c|l|c|r|}
\hline No & Rating stages & $\begin{array}{c}\text { Aspect } \\
\text { average }\end{array}$ & Presentase \\
\hline 1 & Preparation & 3,5 & $70 \%$ \\
\hline 2 & $\begin{array}{l}\text { Game Product } \\
\text { Making }\end{array}$ & 4 & $80 \%$ \\
\hline 3 & $\begin{array}{l}\text { Product } \\
\text { Rating }\end{array}$ & 3,75 & $75 \%$ \\
\hline
\end{tabular}

From the results of the assessment of pencak silat basic motion game products by sports experts obtained an average range of scores of $3.5-4.00$ with a percentage of $70 \%-80 \%$.

2. Final Product Validation

a. Sports Expert

The results of the final product validation from sports experts are as follows:

TABLE 5. SPORTS EXPERT END PRODUCT VALIDATION

\begin{tabular}{|c|c|c|c|}
\hline No & Rating stages & Aspect average & Presentase \\
\hline 1 & Preparation & 4 & $80 \%$ \\
\hline 2 & $\begin{array}{c}\text { Game Product } \\
\text { Making }\end{array}$ & 4,16 & $83,33 \%$ \\
\hline 3 & Product Rating & 4,5 & $90 \%$ \\
\hline
\end{tabular}

From the results of the assessment of pencak silat basic motion game products by sports experts obtained an average range of scores of 4.00-4.5 with a percentage of $80 \%-90 \%$. The 
results of the validation of the final product of the sports expert can be concluded that the basic game of pencak silat for early age is declared "valid" and can be used.

b. Holy Tread Swordsman

The results of the final product validation from the tread holy experts are as follows:

TABLE 6. VALIDATION OF THE FINAL PRODUCT OF THE TAPAK SUCI EXPERT

\begin{tabular}{|c|c|c|c|}
\hline No & Rating stages & $\begin{array}{c}\text { Aspect } \\
\text { average }\end{array}$ & Presentase \\
\hline 1 & Preparation & 4,75 & $95 \%$ \\
\hline 2 & $\begin{array}{c}\text { Game Product } \\
\text { Making }\end{array}$ & 4,83 & $96,6 \%$ \\
\hline 3 & Product Rating & 4,5 & $90 \%$ \\
\hline
\end{tabular}

From the results of the assessment of pencak silat basic motion game products by sports experts obtained an average range of scores of 4.5-4.83 with a percentage of $90 \%-96.6 \%$. The results of the validation of the final product of the holy warrior expert can be concluded that the basic game play of pencak silat for an early age is declared "valid" and can be used.

c. Expert Teacher of Pencak Silat Middle School Muhammadiyah

The results of the final product validation from the martial arts expert are as follows:

TABLE 7. FINAL PRODUCT VALIDATION EXPERT IN MARTIAL ARTS TEACHER AT SD MUHAMMADIYAH

\begin{tabular}{|c|c|c|c|}
\hline No & Rating stages & Aspect average & Presentase \\
\hline 1 & Preparation & 4,25 & $85 \%$ \\
\hline 2 & $\begin{array}{c}\text { Game Product } \\
\text { Making }\end{array}$ & 4,3 & $86,6 \%$ \\
\hline 3 & Product Rating & 4,25 & $85 \%$ \\
\hline
\end{tabular}

From the results of the assessment of pencak silat basic motion game products by sports experts obtained an average range of scores of 4.25-4.3 with a percentage of $85 \%-86.6 \%$.The results of the validation of the final product of the holy warrior expert can be concluded that the basic game play of pencak silat for an early age is declared "valid" and can be used.

\section{E. Product Trial}

\section{1) Small Product Trial}

A small-scale trial was applied at SD Muhammadiyah Tanjung Sari with a trial subject of 30 elementary students. The results of testing the basic motion game products pencak silat that is obtained responses of test subjects with an average range of aspects of answers 3.16-3.54 and the percentage range of $79.81 \%-88.54 \%$.

\section{2) Large Product Trial}

A small-scale trial was applied to the Muhammadiyah Tanjung Sari Elementary School with 100 elementary school students as the test subjects. The results of trials of pencak silat basic motion game products that obtained test subjects' responses with an average range of answer aspects 3.41-3.83 and the percentage range of $85.41 \%-95.83 \%$.

\section{F. Product Revision}

\section{1) Small Product Trial Revision}

TABLE 8. THE RESULTS OF THE REVISION OF A SMALL TRIAL EXPERT IN THE BASIC MOTION GAME PENCAK SILAT

\begin{tabular}{|c|c|c|}
\hline Expert & Revision & Repair \\
\hline \multirow{4}{*}{ Sports Expert } & $\begin{array}{l}\text { Add Description of } \\
\text { Game } \\
\text { Implementation }\end{array}$ & $\begin{array}{l}\text { Making the } \\
\text { implementation of } \\
\text { every basic game of } \\
\text { pencak silat }\end{array}$ \\
\hline & $\begin{array}{l}\text { Change the } \\
\text { implementation of } \\
\text { techniques in the } \\
\text { game from stabbing } \\
\text { opposition to sickle } \\
\text { kicks }\end{array}$ & $\begin{array}{l}\text { Change the stab kick } \\
\text { to the sickle kick }\end{array}$ \\
\hline & $\begin{array}{l}\text { Clarify the game } \\
\text { image }\end{array}$ & $\begin{array}{l}\text { Make the game image } \\
\text { design clearer }\end{array}$ \\
\hline & $\begin{array}{l}\text { Add instructions to } \\
\text { compete to finish } \\
\text { the game quickly }\end{array}$ & $\begin{array}{l}\text { Add instructions } \\
\text { instructor teachers to } \\
\text { compete with each } \\
\text { other to finish the } \\
\text { game with the right } \\
\text { technique }\end{array}$ \\
\hline \multirow{4}{*}{$\begin{array}{l}\text { Ahli Pendekar } \\
\text { Tapak Suci }\end{array}$} & $\begin{array}{l}\text { The picture is not } \\
\text { clear enough }\end{array}$ & $\begin{array}{l}\text { Clarify images with a } \\
\text { variety of colors }\end{array}$ \\
\hline & $\begin{array}{l}\text { Substitute the use } \\
\text { of cardboard box } \\
\text { target media with } \\
\text { folifom foam }\end{array}$ & $\begin{array}{l}\text { Replacing the box } \\
\text { with polyphomic } \\
\text { foam }\end{array}$ \\
\hline & $\begin{array}{l}\text { Make a color on } \\
\text { each target }\end{array}$ & $\begin{array}{l}\text { make the target kick } \\
\text { with color }\end{array}$ \\
\hline & $\begin{array}{l}\text { Make a sign to kick } \\
\text { and hit }\end{array}$ & $\begin{array}{l}\text { make a cone for the } \\
\text { martial arts step } \\
\text { direction }\end{array}$ \\
\hline \multirow{3}{*}{$\begin{array}{l}\text { Expert Teacher } \\
\text { of Pencak Silat } \\
\text { Muhammadiyah }\end{array}$} & $\begin{array}{l}\text { Make an } \\
\text { explanation for } \\
\text { each technique } \\
\text { performed }\end{array}$ & $\begin{array}{l}\text { make the } \\
\text { implementation of the } \\
\text { basic techniques } \\
\text { carried out }\end{array}$ \\
\hline & $\begin{array}{l}\text { clarify the purpose } \\
\text { of the game }\end{array}$ & $\begin{array}{l}\text { Attach objectives to } \\
\text { the manual in every } \\
\text { basic motion game }\end{array}$ \\
\hline & $\begin{array}{l}\text { Add a description } \\
\text { of the time in } \\
\text { playing the game }\end{array}$ & $\begin{array}{l}\text { Limiting the time of } \\
\text { each game is } 5 \\
\text { minutes }\end{array}$ \\
\hline
\end{tabular}




\section{2) Large Product Trial Revisions}

TABLE 9. THE REVISION OF A TRIAL EXPERT FOR A LARGE PRODUCT BASED ON THE BASIC MOTION GAME OF MARTIAL ARTS AT SD MUHAMMADIYAH TANJUNG SARI.

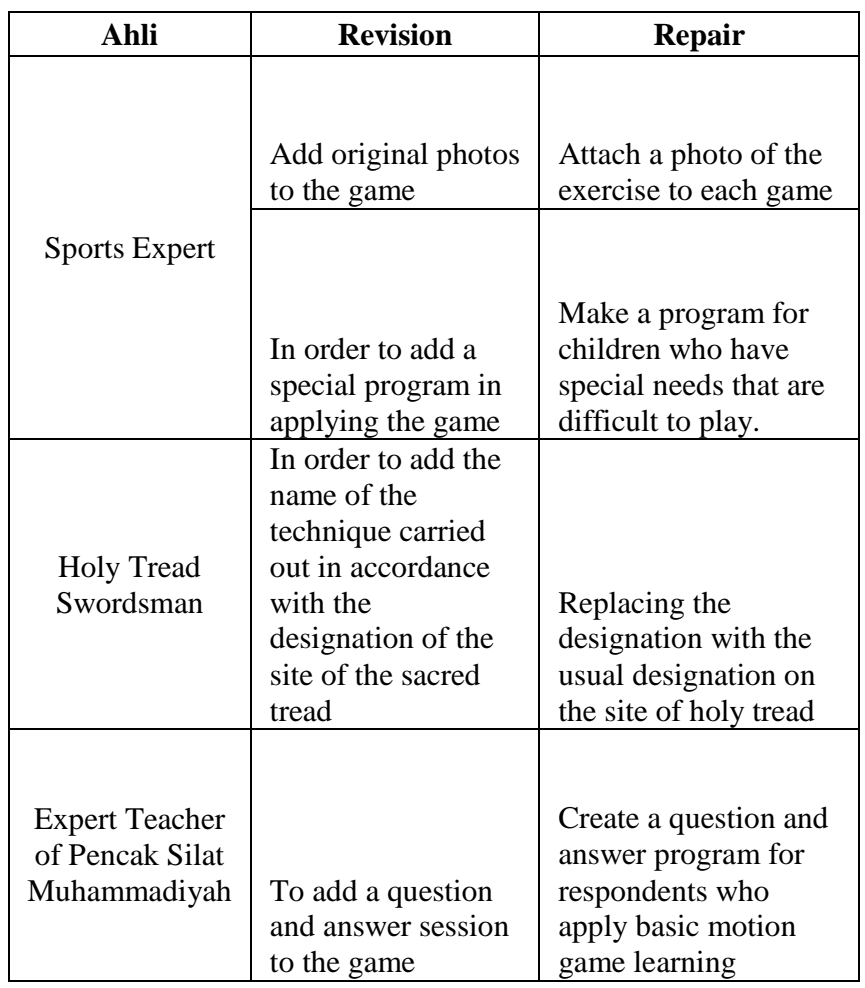

\section{RESULT AND DISCUSSION}

The level of effectiveness of pencak silat basic motion play from the three experts in small trials to large scale silat trials namely:

TABLE 10. THE AVERAGE ASPECT SCORE OF EXPERT ANSWERS

\begin{tabular}{|l|r|r|}
\hline \multirow{2}{*}{\multicolumn{1}{|c|}{ Expert }} & \multicolumn{2}{c|}{ Aspect of Average Score } \\
\cline { 2 - 3 } & \multicolumn{1}{|c|}{ Testing I } & Testing II \\
\hline Sports Expert & 3,66 & 4,22 \\
\hline Holy Tread Swordsman & 4,22 & 4,69 \\
\hline Martial Arts Teacher & & \\
Expert at & & \\
Muhammadiyah & & \\
Elementary School & 3,75 & 4,27 \\
\hline
\end{tabular}

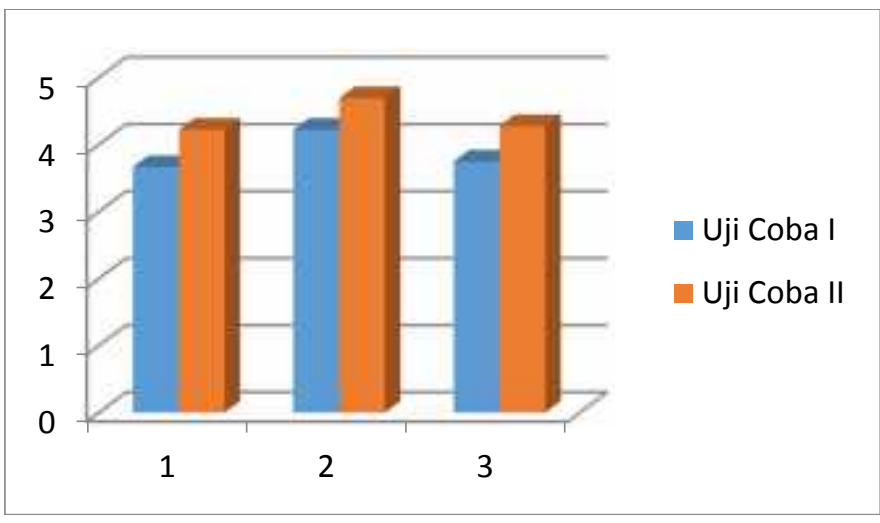

Fig. 1. Histogram of small-scale trial product assessment

Percentage of basic movements of pencak silat from the three experts in small trials to large scale trials, namely:

TABLE 11. PERCENTAGE OF EXPERT ANSWERS

\begin{tabular}{|l|r|r|}
\hline \multirow{2}{*}{\multicolumn{1}{|c|}{ Expert }} & \multicolumn{2}{c|}{ Presentage } \\
\cline { 2 - 3 } & \multicolumn{1}{|c|}{ Testing I } & \multicolumn{1}{c|}{ TestingII } \\
\hline Sports Expert & $74,28 \%$ & $84,28 \%$ \\
\hline Holy Tread Swordsman & $84,28 \%$ & $94,28 \%$ \\
\hline $\begin{array}{l}\text { Martial Arts Teacher } \\
\text { Expert at }\end{array}$ & & \\
$\begin{array}{l}\text { Muhammadiyah } \\
\text { Elementary School }\end{array}$ & $75,71 \%$ & $85,71 \%$ \\
\hline
\end{tabular}

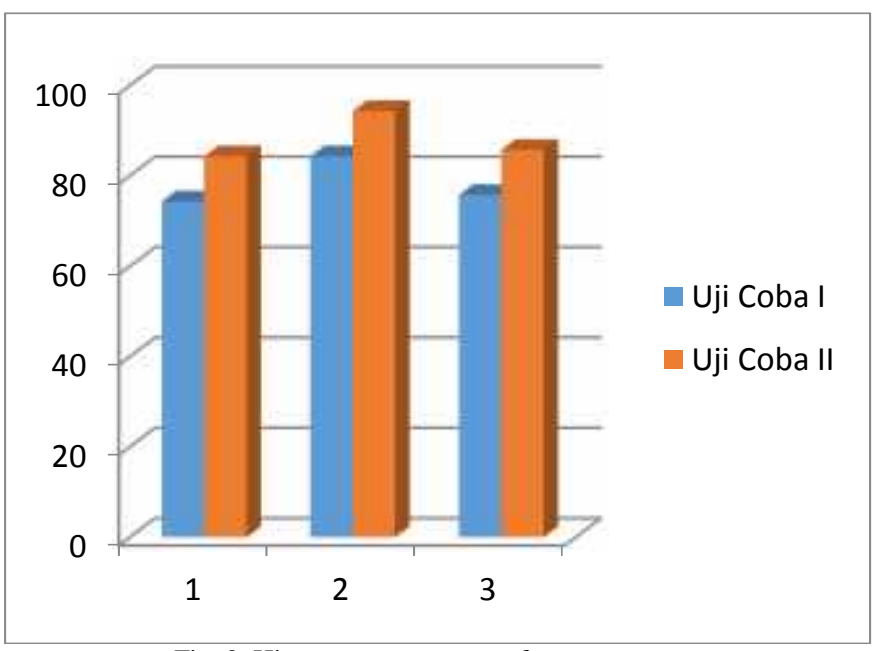

Fig. 2. Histogram percentage of expert answers

The results of respondents' answers on the development of pencak silat basic motion games are as follows: 


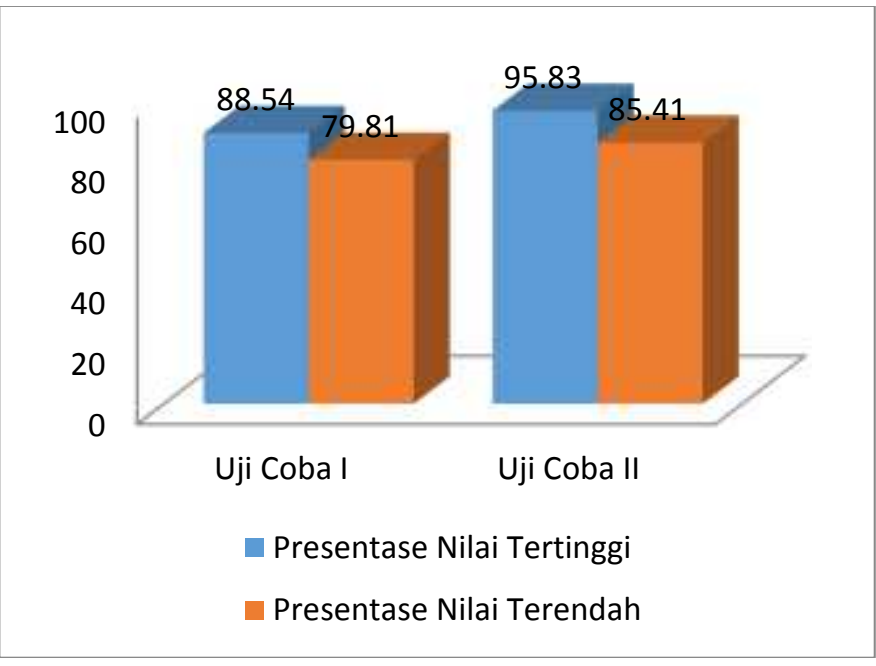

Fig 3. Histogram of Respondent / Student Answers

From the above histogram it can be concluded that there is an increase in the percentage of students' answers to the basic movements of pencak silat.

\section{CONCLUSION}

From the discussion of the results of the basic movements of pencak silat at Muhammadiyah Tanjung Sari Elementary School, conclusions can be drawn:

1. Research The development of the basic movements of pencak silat consists of1)potential problem 2)Data collection 3)Product Design 4)Validation 5)Revision Product 6)Product Trial.

2. Pencak Silat's basic motion game has 20 variations of games that fit the characteristics of early childhood.

3. The results of expert validation on the effectiveness of pencak silat basic motion game products obtained an average aspect score of the answers of the three experts in a small trial of 3.66-4.22 with a percentage range of $74.28 \%-84.28 \%$.

4. The results of expert validation on the effectiveness of pencak silat basic motion game products obtained an average aspect score of the answers of the three experts in a large trial of 4.22-4.69 with a percentage range of $84.28 \%-94.28 \%$.

5. The results of respondents on the development of pencak silat basic motion obtained a small product trial percentage range of $79.81 \%-88.54$ and trials of large products $85.41 \%-95.83 \%$.

\section{REFERENCES}

[1] Albadi S dan Nono Hardinoto, Motor Kontrol Dalam Pendidikan Jasmani Dan Olahraga Pada Usia Dini. Medan, 2014, Medan: Unimed Press, Universitas Negeri Medan

[2] Alfian Riyatno, Ian, Pengembangan Model Pembelajaran Keterampilan Motorik Berbasis Permainan (Penelitian Pengembangan Materi Ajar Pendidikan Jasmani Olahraga Dan Kesehatan Untuk Anak Sekolah Dasar Usia 9-10 Tahun, 2017, Solo: Universitas Sebelas Maret

[3] Ateng, Abdul Kadir, Asas dan Landasan Pendidikan Jasmani, 1992. Jakarta: Depdikbud Dirjen Dikti Proyek Pembinaan Tenaga Kependidikan

[4] Cholik Mutohir, Toho, Gagasan-gagasan tentang Pendidikan Jasmani dan Olahraga, 2002, Surabaya: Unesa University Press

[5] Gallahue L. David and Ozmum C John, Understanding Motor Development : Infants, Children, Adolescents, Aduls, Mc Graw Hill, 2004, Six Edetion, New York

[6] Husdarta H.J.S, Manajemen Pendidikan Jasmani, 2010, Bandung: Alfabeta

[7] Johansyah, Lubis dan Hendro Wardoyo, Pencak Silat, 2014, Jakarta: Raja Wali Sport

[8] Kemenegpora. 2007. Undang-Undang Republik Indonesia Nomor 3 Tahun 2005; Tentang Sistem Keolahragaan Nasional. Jakarta: Kemenegpora

[9] Lutan, Rusli, Hartoto dan Tomoliyus. 2001. Pendidikan Kebugaran Jasmani ; Orientasi Pembinaan di Sepanjang Hayat. Jakarta: Direktorat Jenderal Pendidikan Dasar dan Menengah, Departemen Pendidikan Nasional, bekerjasama dengan Direktorat Jenderal Olahraga

[10] Majid, Abdul. 2005. Perencanaan Pembelajaran (Mengembangkan Kompetensi Guru), Bandung: Remaja Rosdakarya

[11] Perkembangan Berdirinya Seni Ilmu Beladiri Indonesia Pergururan Tapak Suci Putera Muhammadiyah. 2017. Medan: Daftar Pustaka Depertemen Pustaka Perguruan Seni Ilmu Beladiri Indonesia Tapak Suci Putera Muhammadiyah

[12] Rahyubi, Heri. 2012. Teori-Teori Belajar Dan Aplikasi Pembelajaran Motorik Deskripsi Dan Tinjauan Kritis. Bandung: Nusa Media

[13] Ruhimat, ddk. 2009. Kurikulum dan Pembelajaran. Buku Pegangan Dosen dan Mahasiswa (MKDP). Bandung: Jurusan Kurikulum dan Teknologi Pendidikan

[14] Sadiman, Arif S. 2003. Media Pendidikan Pengertian, Pengembangan dan Pemanfaatanya. Jakarta: Pustekum Dikbud

[15] Sugiyono. 2008. Metode Penelitian Kuantitatif, Kualitatif dan R \& D. Bandung: Alfabeta

[16] Sudjana. 2010. Penilaian Hasil Proses Belajar Mengajar. Bandung: PT Remadja Fosdakarya

[17] Sumantri. 2005. Model Pengembangan Keterampilan Motorik Anak Usia Dini. Jakarta: Bumi Aksara

[18] Suryadi, Damanik. 2014. Olahraga Rekreasi Prinsip dan Aplikasi. Medan: Unimed Press. Universitas Negeri Medan

[19] Sukintaka. 2004. Filosofi, Pembelajaran, dan Masa Depan Teori Pendidikan Jasmani. Bandung: Nuansa

[20] Syarifuddin, Aib dan Nurhadi. 1992. Pendidikan Jasmani dan Kesehatan. Jakarta: Depdikbud. Dirjendikti. Proyek Pembinaan Tenaga Kependidikan

[21] Tedjasaputra, Mayke s. 2001. Bermain, Mainan dam Permainan Untuk Pendidikan Anak Usia Dini. Jakarta: Grasindo

[22] Tim Pascasarjana UNIMED. 2014. Pedoman Administrasi dan Penulisan Tesis \& Disertasi. Medan: Program Pascasarjana Universitas Negeri Medan

[23] Undang-Undang republik Indonesia Nomor 20 Tentang sistem pendidikan nasional. 2003. Jakarta: Sekretariat Negara 